\title{
VIELÄ MARXISMISTA, RATIONALISMISTA JA IRRATIONALISMISTA
}

Tiede ja edistyksen numerossa 3/79 ilmestyi Sakari Hännisen puheenvuoro, joka liittyi Suomessa viime aikoina - tosin hieman kivuliaasti - käynnistyneeseen irrationalismikeskusteluun. Hänninen toivoo, että "suomalaiset marxilaiset tutkijat ryhtyisivät siihen spesifisti marxismin metodologiseen ja tieteenfilosofiseen keskusteluun, jota ei Suomessa koskaan käyty"'. Tätä minäkin toivon. Siksi olen kirjoittanut tämän puheenvuoron. Kysymykset maailmankatsomuksesta ovat nykyisin ilmassa - se näkyy esimerkiksi uusissa nuorisoliikkeissä, sellaisten lehtien kuin "Genesis" ja "Uuden Ajan Aura" ilmaantumisessa, ja samalla tilanne on meille marxilaisille tietty "memento".

\section{Rationalismin eri muodoista}

Lähtökohta on siis irrationalismi tai yhä hyvin sen vastapooli rationalismi. Kuten Hänninenkin nähdäkseni aivan oikein toteaa, keskustelusta on tähän asti ollut vaikeata saada pitävää otetta siksi, että siinä käytetyt käsitteet tuntuvat välistä olevan liukkaita kuin tuore ankerias. Yritän siksi sanoa sanottavani omalta osaltani mahdollisimman selvästi.

"Rationalismi" -termillä osoittautuu olevan kaksi aivan eri laajuista sovellutusaluetta. Ensimmäinen viittaa rationalismiin $\mathrm{em}$ pirismin vastakohtana, ajattelutapana, joka korostaa järjen prioriteettia aistikokemukseen ja havaintoihin nähden; toinen taas viittaa rationalismiin irrationalismin vastakohtana, ajattelutapana, joka haluaa kytkeä maailmankatsomuksen luonnon ja yhteiskunnan lainmukaisuuksiin ja pitää samalla näitä lainmukaisuuksia tiedostettavina sekä ihmisen tavoitettavissa olevina. Mikäli tulkitsemme "rationalismin" tällä jälkimmäisellä tavalla, niin enpä usko löytyvän montakaan marxistia, joka ei allekirjoittaisi teesiä marxismin rationalismista. Ja tähän Hänninenkin nähdäkseni yhtyy Mannisen tekstiä arvioidessaan.
Esitetyt "rationalismi" -käsitteen kaksi eri sovellutusaluetta eivät kuitenkaan ole nïn vastakohtaisia toisiinsa nähden kuin mitä ensi silmäyksellä ehkä näyttää. Pikemminkin on niin, että ne kytkeytyvät elimellisesti yhteen. Porvarillisen ajattelun varhaisemman vaiheen, 1600-1700 -lukujen filosofian "rationalismi vs. empirismi" -vastakohta on 1900-luvulle tultaessa muuttanut muotoaan ja kasvanut orgaanisesti "rationalismi vs. irrationalismi" -vastakohdaksi hieman samaan tapaan kuin puunrunkoon tulee jatkuvasti uusia vuosirenkaita. Kehityksellä on yhteisiä nimittäjiä, ja niiden oivaltaminen antaisi käytävälle keskustelulle hieman enemmän konkreettista tuulta siipien alle. (Lisä-aineistoa haluaville viittaan neuvostoliittolaisen filosofin Mihail Kisselin teokseen "'Sudba staroi dilemmy: ratsionalizm i empirizm v buržuaznoi filosofii XX veka", Moskva 1974).

Rationalismin ja empirismin klassinen vastakkainasettelu pohjautui uuden ajan tieteen synnyttämän tilanteen filosofiselle refleksiolle. Lyhyesti, siinä ratkaistiin kahdella eri tavalla filosofian ja tieteen suhde. Rationalismin ytimenä oli tällöin ajatus, että inhimillinen tiedostus ei redusoidu (kokeellisen) tieteen meille välittämään aineistoon, vaan ajattelussa on, kun se pyrkii haltuunottamaan konkreettisen maailman objekteja, tiettyä yleispätevää ja välttämätöntä, tiettyjä universaalisia lainmukaisuuksia ilmaiseva taso. Rationalismi korosti siis $f i$ losofis-maailmankatsomuksellisen momentin määrättyä itsenäisyyttä. Näin ajattelivat muun muassa Descartes, Spinoza, Leibniz. Sen sijaan empirismi pyrki muokkaamaan filosofian kokeellisten tieteiden esikuvan mukaiseksi; tämän suhtautumistavan kantaisänä voidaan pitää Francis Baconia. Myöhemmin on empirismin keskeinen idea pyritty - tietysti jossain määrin yksipuolistaen - tiivistämään teesiin: "Nihil est in intellectu, quod non prior fuit in sensu", ymmärryksessä ei ole mitään, mitä ei olisi aisteissa (aistikokemuksessa).

Rationalismin ja empirismin kiistan eräänä ytimenä oli siis kysymys siitä, onko filosofialla oikeus omaan itsenäiseen olemassaoloonsa, onko sillä omat spesifiset välineensä todellisuuden haltuunottamiseksi vai onko filosofia muutettava eräänlaiseksi erillistieteeksi.

Klassinen rationalismi ei kuitenkaan kyennyt viemään ohjelmaansa läpi. Sen lähtökohta-asettamukset johtivat viime kädessä perusteettomaan empirian halveksuntaan ja spekulatiiviseen konstruointiin tietyistä apriorisina pidetyistä premisseistä käsin. Hänninen viittaa artikkelissaan oikeutetusti Hegelin, viimeisen klassisen rationalismin ihanteita toteuttamaan pyrkivän filosofin "'antikvoituneisuuteen" esimerkiksi historiankäsityksen alalla. Hegel yritti rationalistista maailmanhistorian konstruointia. Hän piti historiallista prosessia (so. vapauden periaatteen realisoitumista) loogisena prosessina. Ja juuri tässä piili ratkaisematon antinomia. Looginen prosessi ei nimittäin voi olla liikettä ajassa eikä paikassa, kun taas historia, todellinen historia, on juuri tätä. Ei ole mikään ihme, että Hegelin jälkeinen irrationalistinen saksalainen filosofia (jo Schopenhauer!) kielsi yleensä historian loogisen selittämisen mahdollisuuden ja toteutti jyrkän käänteen anti- ja ylihistorismiin. Kuten Manninen huomauttaa omassa puheenvuorossaan (Soihtu 3/1979), porvarillisessa historiankirjoituksessa 1800-luvun puolivälinkin jälkeen syntynyt ns. historismin periaate liittyy tähän rationalistisen historiantulkinnan vararikkoon: ihmisten ja historian maailma pyrittiin erottamaan lainmukaisuuksia etsivistä tieteistä, ts. historiallinen ja looginen erotettiin toisistaan, niiden välille pystytettiin Kiinan muuri. 


\section{Nykyisen rationalismi- irrationalismi \\ -asetelman synty}

Klassisen rationalismin epäonnistuminen viime vuosisadan puolimaille saavuttaessa on se solmukohta, jossa siihenastinen rationalismin ja empirismin puitteissa pysynyt maailman selittämisen tapojen vastakohtaisuus alkaa modifioitua laaja-alaisemmaksi ja mutkikkaammaksi rationalismin ja irrationalismin vastakkaisuudeksi. Porvarillisen yhteiskunnan antinomioiden syveneminen antoi tälle kehitykselle sosiaalisen kaikupohjan. M. A. Kissel kuvaa tapahtunutta käännettä seuraavin sanoin:

'Spekulatiivisen filosofian - rationalistisen systeeminrakentamisen - romahduksen tapahduttua Schopenhauer ja Kierkegaard julistivat sen tieteen ja erityisesti teoreettisen ajattelun epämielekkään jäljittelyn seuraukseksi. Heidän mielestään filosofian oli kuljettava omaa tietään suomatta silmäystäkään tieteen suuntaan, ja vieläpä selvästi tiedostettava sekä kohteensa että metodinsa yhteensopimattomuus tieteen kanssa. Näin syntyy irrationalismin liike, joka samalla kertaa oli (ja on) sekä rationalismin leppymätön vihollinen että sen tunnustamaton perillinen" (mt., ss. 164-165).

Irrationalismiko muka osittain klassisen rationalismin perillinen? Kyllä, nimenomaan näin on. Juuri porvarillinen irrationalistinen filosofia säilytti näkemyksen filosofiasta oppina maailmasta kokonaisuutena ja ihmisen asemasta siinä. Juuri irrationalistinen filosofia jatkoi porvarillisessa ajattelutraditiossa näkemystä, jonka mukaan filosofialla on tiettyjä erillistieteisiin redusoitumattomia maailmankatsomuksellisia funktioita. Mutta irrationalistinen filosofia joutui samalla eräässä ratkaisevassa kohdassa ristiriitaan klassisen tradition kanssa - sen oli kiistettävä filosofian mahdollisuus antaa todellisuudelle järjellinen, rationaalinen tulkinta. Todellisuus on irrationalistille "'konkreettinen", mutta konkreettinen nimenomaan siinä mielessä, että sitä ei voi kuvata abstrakteilla, "intelligiibeleillä", "tieteellisillä", termeillä. Sitä ei voi tavoittaa asioiden ja olioiden yleisiä yhteyksiä ja lainmukaisuuksia etsivällä järjellä. Vanha Schelling ilmaisi tämän irrationalismin ajatuksen sanomalla, että itse olemassaolon fakta, "das Das", sekä tämän olemassaolon olemuksen järkiperäinen määrittely, "das Was", eivät voi kohdata toisiaan. Vastaavanlainen erottelu löytyy myös esimerkiksi Heideggeriltä, jonka terminologia tekee eron "ontisen" (esineellis-olemuksellisen) ja "ontologisen" (mikä ilmaisee olemista sellaisenaan) välillä. Syntyy idea irrationaalis-konkreettisesta "elämänmaailmasta", Lebenswelt, jonka rationaalinen hahmottaminen ei ole mielekästä. Irrationalismi siis kykenee säilyttämään filosofian autonomian ainoastaan irroittamalla filosofian myönteisistä tehtävistään.

Positivismı puolestaan etenee toista tietä, jonka empirismi oli viitoittanut. Vanhan empirismin tavoin se hylkää ajatuksen filosofian maailmankatsomuksellisista (syntetisoivista) funktioista ja pyrkii palauttamaan filosofian erilaisiin intellektin analyyttisiin toimintoihin, so. jäljittelemään "positiivisten tieteiden" mallia myös filosofiassa. Tämän tien eräänä päätepisteenä on Wittgensteinin oppi, jossa filosofialle ei jää muuta tehtävää kuin kielianalyysi, "'metafyysisen sairauden' terapeuttinen lievittäminen. Näemme siis, ettei positivismi ainakaan tässä suhteessa ole millään muotoa klassisen rationalismin perillinen. Se on päinvastoin vanhan empiristisen tradition muuan pääteasema, jolle saavuttua ihanne synteesistä on joutunut kadotetun matkatavaran joukkoon ja lattea (kieli)analyysi nähdään ainoana mahdollisuutena.

On muuten kiintoisaa, että positivismin kriisi on porvarillisessa ajettelussa johtanut eräiden rationalismin asettamusten restauraatioon. Niinpä esimerkiksi Thomas S. Kuhn on pyrkinyt osoittamaan, kuinka todellisessa, aktuaalisessa tieteessä ei suinkaan operoida "puhtaalla" havaintobaasiksella, vaan tieteen tekemisessä on aina mukana, joko kätketysti tai ilmeisenä, määrätty teoreettis-metodologinen vakaumuspohja. Kuhn yhtyy tällä "löydöllään" vanhaan rationalistiseen "tabula rasa" -konseption kritiikkiin ja osoittaa samalla, mikä klassisessa rationalismissa oli säilyvää ja arvokasta. Intellektissä todella on jotain sellaista, mitä aisteissa ei ole!

\section{Marxismin tehtävistä}

Palaan vielä Hännisen esimerkkiin Hegelin "antikvoituneisuudesta" historianfilosofian alalla. Se oli hyvin valittu ja hedelmällinen, pitkään kontroversioon mahdollisuuden tarjoava esimerkki, joskaan en aivan täysin haluaisi yhtyä siihen Hännisen näkemykseen, että juuri Marx-Hegel -suhteen eksplikaatio olisi tämän hetken keskustelun kannalta keskeisin tehtävä. Eihän hegelismi ole koko filosofia.

On tunnettua, että marxismin klassikot kritisoivat Hegelin spekulatiivista metafysiikkaa. Mutta hylkäsivätkö he Hegelin rationalismin? Eivätpä suinkaan. Päinvastoin, he puhuivat suurella empatialla Hegelin opin "rationaalisesta ytimestä", jonka omaksuminen on välttämätöntä työväenluokan teorianmuodostukselle. "Rationaalinen ydin" - se oli Hegelin luottamus ihmisjärjen mahdollisuuksiin tavoittaa ja selittää ympäröivää todellisuutta ei vain ahtaan erillistieteellisesti, vaan myös filosofis-maailmankatsomuksellisella tasolla, ei vain erityisessä, vaan myös yleisessä.

Marxin oppi loogisesta ja historiallisesta kapitalismin genesiksessä on nähtävä ratkaisuna siihen Hegelin historianfilosofian dilemmaan, josta yllä jo puhuttiin. Se on, Marxin sanoin, "ajattele- 
van pään" tapa haltuunottaa reaalinen kehitys sille ominaisella tavalla, tavoittaa todellinen historiallinen prosessi rationaalis-dialektisesti ja samalla materialistisesti kytkemällä se loogiseen esitykseen.

Hegelin filosofian merkitys marxismin kannalta ei tietysti rajoitu sen rationalismiin; myös Hegelin suorittama käsitteiden ja kategorioiden dialektinen kehittely on marxismin kannalta merkittävää pohjustus- ja valmistelutyötä. Mutta sikäli kun puhumme Hegelin rationalismin ytimestä, sen arvosta marxismille, niin se piilee juuri ideassa filosofian syntetisoivasta funktiosta. Filosofia ei marxismille enää ole spekulatiivista konstruktiota; jo Feuerbach kaatoi nämä harhakuvat. Mutta filosofian maailmankatsomustehtävä ei katoa, vaikka filosofia "vanhassa mielessä", so. erillistieteistä irrallisena systeeminä lakkaakin olemasta; vanhan rationalismin näkemys filosofian merkityksestä säilyy marxismissa: se on oppia "'kokonaisyhteydestä" (Engelsin termi: Gesamtzusammenhang), maailman yleisistä lainmukaisuuksista ja olioiden periaatteellisesta tiedostettavuudesta.

Pantakoon merkille: vanhan rationalismin eräät asettamukset ovat edelleenkin ajankohtaisia marxismin kannalta juuri siinä, että ne tarjoavat mahdollisuuden erillistieteiden aineiston maailmankatsomukselliseen muokkaamiseen. Näin sanoessani ajattelen esimerkiksi L. S. Vygotskia, joka kehitellessään marxilaista psykologiaa piti tarpeellisena palata Spinozan kehittelemän "rationaalisen psykologian"' filosofisiin ideoihin, varsinkin Spinozan oppiin emootioista. (Tämän täytyy tässä yhteydessä jäädä vain viittaukseksi; ks. Vygotskyn postuumia artikkelia lehdessä "Voprosy Filosofi" 6/1970 sekä P. J. Galperinin esipuhetta siihen). Toistan vielä kerran, että (lattea) empirismi ja varsinkaàn positivismi eivät ole avuksi maa- ilmankatsomuksellisten ongelmien pohdiskelussa - paitsi mikäli Kuhnin tavoin pyritään osoittamaan niiden piilevät maailmankatsomukselliset postulaatit (eli toisin sanoen, osoittamaan, mikä "empirismissä" sittenkin on "rationalistista'"!).

Tulemme nyt oman juttuni varsinaiseen sanottavaan. Se on tämä: kysymys rationalismista ja empirismistä, rationalismista ja irrationalismista ei ole vain kysymys siitä, onko todellisuus järkevää vai ei, onko sen järjellinen haltuunotto mahdollista vai ei; se on ennen kaikkea kysymys siitä, onko todellisuuden kokonaisvaltainen, filosofis-maailmankatsomuksellinen omaksuminen mahdollista järjen keinoin vai ei, vai onko ajattelu tuomittu nojautumaan ahtaaseen, "'epäilevään, epäluuloiseen, puolitettuun järkeen" (Manninen). Kysymys on filosofian statuksesta. Väitän, että järki, ratio, ei voi täysin realisoitua, jos siltä evätään filosofis-maailmankatsomuksellisen refleksion taso.

Näen keskustelutilanteen tällä hetkellä sellaisena, että filosofian (ja maailmankatsomuksen) statuksen ongelma on eräs taustalla olevista selvittämättömistä kysymyksistä, niemenomaan suomalaisten marxilaisten parissa.

Lopuksi:

Althusserin koulu-

kunnasta ja muustakin

Jotta artikkelini ei jäisi aivan ilmassa leijuvaksi, yritän lopuksi puuttua tähän asti käytyyn keskusteluun vähän konkreettisemmalla tasolla. Mitä esimerkiksi Althusserin koulukunta väittää? Tällä kertaa en puutu althusserilaisen ajattelun ansiokkaisiin puoliin (niitäkin on!) vaan kysyn ainoastaan sen näkemyksiä filosofian suhteen. Siis, mitä tämä koulukunta väittää? Hieman yksinkertaistaen seuraavaa: filosofia on politiikan ''interventiota"' teoriaan, filosofia on luokkataistelua teorian alalla; filosofialla ei ole positiivista tiedostustehtävää, vaan se on ikäänkuin tyhjä taistelukenttä, jota kansoittavat erilaiset keskenään yhteen ottavat, eri luokkaintressejä edustavat taisteluosapuolet. Filosofia on vain taistelutanner; sillä ei ole omaa kohdetta eikä omaa historiaa (ks. esim. Althusserin teosta "Elemente der Selbstkritik", West-Berlin 1976, s. 86 ja ed.).

Kun filosofia on näin näppärällä silmänkääntötempulla saatu redusoiduksi politiikaksi, on selvää, että myös irrationalismin ongelma joutuu tämäntapaisessa "gallialaisen hengen" valaistuksessa aivan omalaatuiseen varjoon. Kysymys irrationalismista lakkaa yleensäkin olemasta filosofis-maailmankatsomuksellinen kysymys. Siitä tulee tavalla tai toisella poliittinen kysymys. Niinpä Dominique Lecourt, Althusserin oppilas ja aseenkantaja, arvioikin Deleuzen ja Guattarin kirjaa "Anti-Oedipe" aivan odotetusti seuraavin sanoin: "Se on hallitsevan psykiatrian asettamista poliittisesti kyseenalaiseksi"'. Ja jatkossa: "Marxilaisen filosofisen käytännön täytyy tukeutua luokkataistelun nykyisten muotojen konkreettiseen analyysiin määrätyllä hetkellä määrätyssä taloudellisessa yhteiskuntamuodostumassa" (T \& E 2/79, ss. 55, 56).

En usko syyllistyväni pahantahtoiseen väärinlukuun, kun väitän: Lecourt samaistaa irrationalismin maailmankatsomuksellisen arvioinnin ja sen poliittisen merkityksen arvioinnin. Siitä näyttäisi seuraavan, että irrationalistisen ajattelun kanssa olisi mahdollista 'liittoutua"' (ehkei nyt, mutta esimerkiksi tulevaisuudessa, toisenlaisessa tilanteessa) samaan tapaan kuin kommunistit liittoutuvat jonkun tietyn luokan tai ryhmän kanssa poliittisesti, so. käytännön luokkataistelun tasolla. Toivon, että lukija vetää itse johtopäätökset.

Althusserin koulukunta antaa marxismille ja varsinkin marxilaiselle filosofialle nähdäkseni erittäin ahtaan pragmaattisen tulkin 


\section{FILOSOFIASTA, LUOKKATAISTELUSTA JA ALTHUSSERISTA}

nan samaistaessaan sen luokkataisteluun par excellence. Maailmankatsomus ja filosofia redusoituvat pelkäksi "ideologiaksi'. Sellaiset asiat kuin Althusserin taannoinen "'antihumanismi" tai hänen flirttailunsa maolaisuuden kanssa eivät tässä valossa herätä ihmetystä. Kuitenkin on niin, että luokkataistelu $e i$ ole marxismissa päämäärä sinänsä. Luokkataisteluahan esiintyy kaikissa antagonistisissa yhteiskunnissa aivan marxilaisista riippumatta. Marxismin päämäärä on toinen - työväenluokan ja sitä kautta koko ihmiskunnan emansipaatio.

Kysymystä rationalismista ja irrationalismista on marxismissa mielestäni tarkasteltava juuri näiden emansipatoristen näköalojen ja pyrkimysten kannalta. Emme me vastusta irrationalismia siksi, että se on irrationalismia, vaan siksi, että se estää sen, mikä on emansipaation tieteellinen pohja, nimittäin syiden tiedostamisen. Marxismin emansipatorinen sisältö teorian ja maailmankatsomuksen alueella näyttäytyy nähdäkseni juuri siinä, että se paljastaa erilaiset illusoriset tajunnanmuodot - alkaen uskonnosta ja idealistisesta filosofiasta ja päätyen tavarafetišismiin ja monetaarijärjestelmän illuusioihin. Illuusiothan merkitsevät vääristyneitä syy-yhteyksiä, "piiloon" jääneitä kausaalisia suhteita, asioita, jotka ovat jääneet vaille rationaalista selitystä. Ja illuusioiden kritiikki mitäpä muuta se edellyttäisi kuin rationaalista (jos kohta ei välttämättä 'rationalistista"') näkemystä maailmasta?

Vesa Oittinen

\begin{abstract}
"Die dialektische Form der Darstellung ist nur richtig, wenn sie ihre Grenzen kennt."'
\end{abstract}

(Marx, Grundrisse, s. 945.)

Kun toisena Lecourtin haastattelun tekijänä ( $T$ \& E 2/79) olen ainakin osit tain syypää haastattelun virittämään keskusteluun (Hänninen, T \& E 3/79; Oittinen tässä numerossa), katson aiheelliseksi vähän kommentoida tätä keskustelua. Kahdesta syystä: olen ensinnäkin huolissani siitä että haastattelun olennainen viesti ei näytä menneen perille; toiseksi - osittain edellisen seurauksena - keskustelu on ajautunut sellaisille urille, jotka saattavat aiheuttaa sekaannusta ja väärinkäsityksiä. Ensimmäinen koskee irrationalismin marxilaista arviointia, toinen, edellistä yleisemmällä tasolla, marxismin maailmankatsomuksellis-filosofisia tehtäviä.

\section{Keskustelun lähtökohdista}

Hänninen peräänkuuluttaa kirjoituksessaan "marxismin metodologista ja tieteenfilosofista keskustelua, jota Suomessa ei koskaan käyty". Oittinen yhtyy tähän, mutta samalla hän tulkitsee mielestäni varsin omaperäisesti tämän keskustelun luonteen, toisin kuin mitä ymmärrän Hännisen tarkoittaneen.

Yhdyn nimittäin mielelläni Hänniseen sikäli mikäli hän ei tarkoita tällä keskustelulla Oittisen esittämää "maailmankatsomus"-keskustelua. Luulen että Oittisen väärinkäsitykseltä olisi vältytty, jos Hänninen olisi pohtinut ja eritellyt kaipaamansa keskustelun puuttumisen syitä Suomessa. Väitän provokatorisesti että Oittisen tarima filosofis-maailmankatsomuksellinen keskustelu on juuri ollut esteenä Hännisen toivomalle metodologiselle keskustelulle.

En voi enkä pysty tässä ja nyt esittämään 70-luvun marxilaisen opiskelijaliikkeen kriittistä histo- riaa, mutta tietääkseni siellä on viime aikoina korjattu varsin karvain mielin 70-luvun "filosofis-maailmankatsomuksellisen" opiskelun hedelmiä.

Vielä 70-luvun alussa, positivismikritiikissä ja yleisemminkin porvarillisen tieteen kritiikissä oli aineksia sille keskustelulle, jota, kuten Hänninen kirjoittaa, ei sitten käytykään. Mutta kun esim. Helsingin yliopistossa ryhdyttiin ASS: $n$ (jolla oli hegemonia-asema marxilaisen opiskelun pïrissä) opintopiireissä luettamaan $\mathrm{mm}$. "Marxilais-leniniläisen filosofian perusteita", pysähtyi erityisesti opiskelijoiden kohdalla Suomessa varsin lupaavasti alkaneen marxismin opiskelun ja tutkimuksen kehitys, jos ei aivan kokonaan, niin lähes kuitenkin. Käsittääkseni marxilaisten tutkijoiden keskuudessa ollaan sangen yksimielisiä nykyään siitä että tällaisesta autoritaaris-dogmaattisesta "maailmankatsomuksellis-filosofisesta" opiskelusta oli eri tieteenaloilla enemmän haittaa kuin hyötyä.

Kirjoituksensa alussa Oittinen viittaa myös Suomen nykyiseen aatteellis-yhteiskunnalliseen tilanteeseen, jossa "kysymykset maailmankatsomuksesta ovat ilmassa", mikä näkyy esim. ns. uusissa liikkeissä. Tässä tilanteessa Oittinen ilmeisesti näkee marxilaisen "maailmankatsomusfilosofian", intervention mahdollisuuden.

Juuri tämän tilannearvion yhteydessä näen Lecourtin haastattelun tärkeyden. Haastattelussaan Lecourt varoitti meitä juuri siitä mitä Oittinen on nähdäkseni tarjoamassa näille liikkeille. Lecourt tähdensi haastattelussaan ( T \& E 2/79, s. 55) nimenomaisesti, että ne nuoret, joita esim. Anti-Oedipe-teos 'puhuttelee', eivät suinkaan ole "'filosofisen mystifikaation naiiveja, tietämättömiä uhreja, jotka pelkällä rationalistisella nuhdesaarnalla saataisiin taas normaaliin päiväjärjestykseen. Nuhteettomiksi pedagogeiksi muuttuneet marxilaiset näyttävät kuitenkin pysyttävän vain tähän rajoittuneeseen arvi- 